\title{
Corrosion Effects on Residual Structural Capacity of Resins / Exudates Inhibited Steel Reinforcement Flexural Beam
}

\author{
Charles Kennedy, Akpan Paul Paulinus, and Gbinu Samuel Kabari
}

\begin{abstract}
The study investigated the effects of corrosion on the residual structural steel bar capacity of resins/exudates inhibited and non-inhibited reinforced concrete beam members. Steel reinforcements were coated with moringa oleifera lam resins/exudates from trees extract (Inorganic inhibitors), embedded into concrete beam members and exposed to sodium chloride medium representing laboratory harsh saline marine environment. Corrosion acceleration potential test was conducted on 27 samples of non-corroded, uncoated and coated resins/exudates paste thicknesses of steel bar and simulated for 60 days, after 30 days, initial concrete cured. Results obtained showed corrosion potential presence on uncoated members with cracks and spalling. Further recorded results on non-corroded flexural strength test of failure load $\mathbf{2 9 . 0 9 \%}$, midspan deflection $\mathbf{2 8 . 3 0 \%}$, tensile strength $\mathbf{1 2 . 0 3 \%}$ and elongation $31.50 \%$, for coated beam members, failure load $\mathbf{2 9 . 4 2 \%}$, midspan deflection $\mathbf{2 7 . 4 2 \%}$, tensile strength $\mathbf{1 2 . 0 9 \%}$ and elongation $31.80 \%$, for corroded beam members, failure load decreased by $22.50 \%$, midspan deflection increased by $39.30 \%$, tensile strength decreased to $10.17 \%$ and elongation by increased $46.30 \%$. The entire experimental results showed that corroded specimens has lower flexural load, higher midspan deflection, lower tensile strength and higher elongation due to loss of steel bar fibre from degradation effect from corrosion, inhibitors served as protective coating against corrosion, but no strength was added to steel members.
\end{abstract}

Index Terms-Corrosion; Corrosion inhibitors; Flexural Strength; Concrete and Steel Reinforcement.

\section{INTRODUCTION}

Corrosion of reinforcing steel immersed or embedded in concrete lead to the untimely collapse of many structures exposed to unfriendly and environments with harshy weather. Corrosion assumes many forms. The products and results of corrosion occur when there is chemical reaction between metal and its environment. An increase in in the size of reinforcing steel bars such as expansion and volume is the result of rust products, it results to weakness of the reinforcing steel bar cross- sectional area as well reduces the rate of bonding between reinforcing steel bar and concrete thereby creating stress within the concrete surroundings, furthermore, cracking and spalling of concrete is noticed due to severe stress which reduces the reinforced concrete structures designed life and durability [1]-[3].

Published on May 16, 2018

C. Kennedy is with Faculty of Engineering, Department of Civil Engineering, Rivers State University, Nkpolu, Port Harcourt, Nigeria (email: ken_charl@yahoo.co.uk).

A. P. Paulinus, and G. S. Kabari are with School of Engineering, Department of Civil Engineering, Kenule Beeson Saro-Wiwa Polytechnic, Bori, Rivers State, Nigeria (e-mail: paulyncia07@gmail.com, kabarisamuel@gmail.com).
Malumbela et al., [4] investigated the corrosion effects of combined sustained loads of corroded reinforced concrete beam for flexural performance. With the application of a $5 \%$ solution of $\mathrm{NaCl}$ on an accelerated corrosion process at constant impressed current induced corrosion on tensile steel bars. They concluded that beam corrosion level is a factor of corrosion level. The increase in flexural cracks reduces with increase in corrosion level and as well as the applied load whereas level of corrosion determines the moment of inertia.

Otunyo and Kennedy [5] investigated the effect of corrosion on the flexural strength and mid-span deflection of steel reinforcements coated with resins / exudates of trees extract known as inorganic inhibitors (dacryodes edulisAfrican Pear). The steel reinforcement members were embedded in concrete and exposed to harsh and saline environments ( $\mathrm{NaCl}$ solution). Corrosion accelerated test were conducted on uncoated and dacryodes edulis resin pastes coated thicknesses of $150 \mu \mathrm{m}, 250 \mu \mathrm{m}$ and $300 \mu \mathrm{m}$ on steel reinforcement before corrosion test for 60 days to simulated corrosion process. Results obtained indicated that the flexural failure strength, and elongation increased by $(29 \%)$ and $(48 \%)$ respectively for the dacryodes edulis coated steel members, the mid-span deflection decreased by $26 \%$, elongation increased by $23 \%$ and $32 \%$ respectively, while the mid-span deflection decreased by $40 \%$. The resin (mdacryodes edulis) added strength to the reinforcement.

Torres-Acosta et al, [6] investigated los of capacity of flexural steel cross-sectional loss of reinforcing steel bar to corrosion level of embedded reinforcement steel bar using specimens of concrete beams with $100 \mathrm{~mm} \times 150 \mathrm{~mm} \mathrm{x}$ $1500 \mathrm{~mm}$ cast with chlorides. Sample specimens in flexure tested under three-point loading were tested. They concluded that flexural load capacity decreased by $60 \%$ with only $10 \%$ ratio, in flexural load capacity were affected in reduction, because pitting corrosion greatly decrease the mechanical properties of reinforcing steel at a certain location and change the steel from ductile behavior to brittle behavior.

El-Maaddawy et al., [7] studied the effect of of corrosion in combined actions of flexural loads of reinforced concrete corroded beams. They found that crack width would propagate $22 \%$ faster in loaded conditions, observed that with $8.9 \%$ and $22.2 \%$ mass loss, strength losses of $6.4 \%$ and $20.0 \%$ respectively.

Huang and Yang [8] investigated the corresponding relationship between the corrosion of reinforced concrete beams and load-carrying capacity. Their results showed that the load carrying capacity reduced significantly reduction due to the increase in corrosion was more in beams with a 
low w/c or predetermined cracks (mix B or type K). They concluded that this behavior was a result of the chloride ions having easier access to the reinforcing steel in cracked beams than in un-cracked ones.

\section{MATERIALS AND METHODS}

\section{A. Materials}

\section{1) Aggregates}

Both fine and coarse aggregates for this research work met the requirements of [9]. They are gotten from Etche River sand dumpsites in Rivers state, while coarse aggregate is gotten crushed rock siite at Akamkpa.

\section{2) Cement}

Ordinary Portland cement used for all concrete mixes in this investigation. The cement met the requirements of [10].

\section{3) Water}

The water samples were clean and free from impurities. The fresh water used was gotten from the tap at the Civil Engineering Department Laboratory, University of Uyo, Uyo. Akwa - Ibom State. The water met the requirements of [11].

\section{4) Structural Steel Reinforcement}

The reinforcements are gotten directly from the market in Port Harcourt met the requirements of [12].

\section{5) Corrosion Inhibitors (Resins / Exudates)}

The study inhibitor (Moringa Oleifera Lam) of natural tree resins/exudates extracts are gotten from bushes and plantations from Odioku communities, Ahoada West Local Government areas, Rivers State, they are sourced from existing and previously formed and by tapping processes for newer ones.

\section{B. Methods}

Present study involves direct application of resins / exudates of trees extract known as inorganic inhibitor (Moringa Oleifera Lam), layered/coated on reinforcement steel ribbed surface. The objective of this study was to determine the usefulness of locally available surfaceapplied corrosion inhibitors under severe corrosive environments and with chloride contamination. The test setup simulates a harsh marine environment of saline concentration.

The samples of reinforced concrete beams of $150 \mathrm{~mm} \mathrm{x}$ $150 \mathrm{~mm} \times 650 \mathrm{~mm}$, thickness, width and length specimens and ribbed bars of $16 \mathrm{~mm}$ embedded for corrosion test and flexural test for beam was investigated. This was aimed at achieving the real harsh and corrosive state, concrete specimens were ponded in solutions $(\mathrm{NaCl})$ and the depth of the solution was maintained for the given period of experiment as to observe the significant changes that resulted from the actions of the accelerator $(\mathrm{NaCl})$ and the specimens. The determination of the contribution of the resins will be observed through its adhesive ability with the reinforcement through surface coating application and the bonding relationship between the coated specimens and concrete, its waterproofing and resistive nature (resistance) against accelerator penetration into the bare reinforcement.

\section{1) Specimen Preparation and Casting of Concrete} Beams

Standard method of concrete blend ratio was followed, batching by using weighing materials manually. Ratio of $1: 2: 4$ concrete blend with the aid of weight and watercement ratio of 0.65 . guide mixing turned into used on a easy concrete banker, and mixture was monitored and water brought gradually to achieve best blend design concrete, preferred uniform shade and consistency concrete was received by way of additions of cement, water and aggregates. The beams were cast in steel mold of size $150 \mathrm{~mm} \times 150 \mathrm{~mm} \times 650 \mathrm{~mm}$. sparkling concrete blend for each batch became completely compacted by using tamping rods, to dispose of trapped air, which could reduce the power of the concrete and $12 \mathrm{~mm}$ and sixteen $\mathrm{mm}$ reinforcements of coated and non-coated had been spaced at a hundred and fifty $\mathrm{mm}$ with concrete cover of $25 \mathrm{~mm}$ were embedded inside the beam and projection of a hundred $\mathrm{mm}$ for half of mobile capacity measurement. Demoulded of specimens was executed after 24 hours and curing lasted for 28 in a curing tanks at room temperature, which then gave manner for extended corrosion take a look at process and testing procedure allowed for 39 days first crack noticed and a further 21 days making a complete of 60 days for in addition observations on corrosion acceleration method.

\section{2) Flexure testing of Beam Specimens}

Universal Testing Machine in accordance with BS EN 12390-2 was used for the flexural test and a total of 56 beam specimens was tested. After curing for 28 days, 6 controlled beam (non-corroded) was kept in a control state, preventing corrosion reinforcement of the, while 18 beam samples of non-coated and resins / exudates coated were partially place in ponding tank for 39 days placed to examine accelerated corrosion process. After 39 days, the accelerated corrosion subjected samples were examined to determine residual flexural strength. Beam specimens were simply supported on a span of $650 \mathrm{~mm}$. An Instron Universal Testing Machine of $100 \mathrm{KN}$ capacity at a slow loading rate of $1 \mathrm{~mm} / \mathrm{min}$ was used in the flexural test. Beam samples were placed in the machine to specification, flexural test were conducted on a third point at two supports. Load was applied to failure with cracks noticed and corresponding values recorded digitally in a computerized system.

\section{3) Tensile Strength of Reinforcing Bars}

To ascertain the yield and tensile strength of tension bars, bar specimens of $12 \mathrm{~mm}$ and $16 \mathrm{~mm}$ diameter of noncorroded, corroded and coated were tested in tension in a Universal Testing Machine and were subjected to direct tension until failure; the yield, maximum and failure loads being recorded. To ensure consistency, the remaining cut pieces from the standard length of corroded and noncorroded steel bars were subsequently used in the bond and flexural test.

\section{RESULTS AND DISCUSSIONS}

Table I is the results of 27 (A-I) samples of flexural strength test of beam specimens, 9 controlled samples of non-corroded normal cured, 9 specimens each of uncoated and coated of moringa oleiferal lam resins / exudates paste of $150 \mu \mathrm{m},(\mathrm{ABC}), 250 \mu \mathrm{m}$ (DEF) and $350 \mu \mathrm{m}(\mathrm{GHI})$. Table 
II, is derived averaged values obtained from Table I for noncorroded, corroded and coated specimens. Fig. 1 and 4 are the plots of generalized and averaged flexural strength failure load versus deflection for non-corroded, corroded and moringa oleifera lam resins/exudates steel coated beam beams. Fig. 3, 5 and 6 are the plots of ultimate tensile strengths versus elongations / strain ratios of general samples and average values derived from Table I.

\section{A. Non-Corroded Concrete Beam members}

Results of non-corroded concrete beams are failure load $29.09 \%$, midspan deflection $28.30 \%$, tensile strength $12.30 \%$ and elongation $31.50 \%$.

\section{B. Corroded Concrete Beam members}

When compared to non- corroded beam members, the flexural strength failure load decreases by $22.5 \%$, midspan deflection increased by $39.30 \%$, tensile strength decreases by $10.17 \%$ and elongation increased by $46.30 \%$

\section{Moringa Oleifera lam coated steel Bar Concrete Beam Members}

When compared to corroded beam members, an increase of $29.42 \%$ flexural strength failure load was recorded, midspan deflection decreased to $27.42 \%$, tensile strength increases by $12.09 \%$ and elongation decreased to $31.80 \%$.

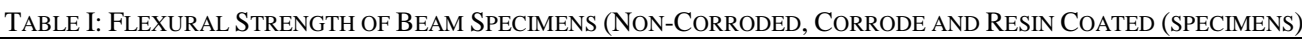

\begin{tabular}{|c|c|c|c|c|c|c|c|c|c|c|}
\hline \multicolumn{11}{|c|}{ Flexure Test Results of Control, Corroded and Resins/exudates Coated Beams. } \\
\hline s/no & \multicolumn{10}{|c|}{ Samples } \\
\hline & & A & $\mathrm{B}$ & $\mathrm{C}$ & $\mathrm{D}$ & $\mathrm{E}$ & $\mathrm{F}$ & G & $\mathrm{H}$ & $\mathrm{I}$ \\
\hline \multicolumn{11}{|c|}{ Non-corroded Control beam } \\
\hline Bk1-1 & Failure load (KN) & 78.08 & 78.08 & 77.90 & 77.87 & 77.87 & 77.98 & 78.68 & 77.65 & 78.80 \\
\hline Bk1-2 & $\begin{array}{l}\text { Midspan deflection } \\
(\mathrm{mm})\end{array}$ & 6.27 & 6.35 & 6.95 & 7.06 & 6.15 & 7.09 & 6.18 & 6.35 & 6.15 \\
\hline Bk1-3 & Bar diameter (mm) & 16 & 16 & 16 & 16 & 16 & 16 & 16 & 16 & 16 \\
\hline Bk1-4 & $\begin{array}{l}\text { Yield Strength, fy } \\
(\mathrm{MPa})\end{array}$ & 460 & 460 & 460 & 460 & 460 & 460 & 460 & 460 & 460 \\
\hline Bk1-5 & $\begin{array}{l}\text { Ultimate Tensile } \\
\text { Strength, fu (MPa) }\end{array}$ & 629.3 & 631.2 & 629.9 & 628.7 & 631.2 & 629.7 & 629.5 & 630.3 & 628.9 \\
\hline Bk1-6 & Strain Ratio & 1.35 & 1.31 & 1.32 & 1.35 & 1.32 & 1.32 & 1.32 & 1.31 & 1.33 \\
\hline Bk1-7 & Elongation $(\%)$ & 26.05 & 26.25 & 26.15 & 26.22 & 25.65 & 25.75 & 26.25 & 26.22 & 26.35 \\
\hline & \multicolumn{10}{|c|}{ Corroded beam } \\
\hline $\mathrm{Bk} 2-1$ & Failure load $(\mathrm{KN})$ & 61.55 & 62.23 & 59.80 & 59.28 & 61.57 & 59.57 & 59.34 & 61.77 & 59.55 \\
\hline $\mathrm{Bk} 2-2$ & $\begin{array}{l}\text { Midspan deflection } \\
(\mathrm{mm})\end{array}$ & 9.52 & 9.35 & 8.98 & 8.95 & 8.55 & 9.45 & 8.98 & 8.58 & 9.25 \\
\hline $\mathrm{Bk} 2-3$ & Bar diameter (mm) & 16 & 16 & 16 & 16 & 16 & 16 & 16 & 16 & 16 \\
\hline Bk2-4 & $\begin{array}{l}\text { Yield Strength, fy } \\
\text { (MPa) }\end{array}$ & 460 & 460 & 460 & 460 & 460 & 460 & 460 & 460 & 460 \\
\hline $\mathrm{Bk} 2-5$ & $\begin{array}{l}\text { Ultimate Tensile } \\
\text { Strength, fu (MPa) }\end{array}$ & 565.3 & 561.9 & 562.5 & 561.8 & 561.5 & 561.8 & 561.2 & 562.5 & 561.8 \\
\hline $\mathrm{Bk} 2-6$ & Strain Ratio & 1.19 & 1.18 & 1.18 & 1.22 & 1.17 & 1.19 & 1.18 & 1.17 & 1.17 \\
\hline $\mathrm{Bk} 2-7$ & Elongation $(\%)$ & 17.91 & 18.05 & 17.72 & 17.25 & 18.24 & 17.53 & 18.05 & 17.75 & 17.76 \\
\hline \multicolumn{11}{|c|}{ Moringa Oleifera lam( steel bar coated specimen) } \\
\hline$\overline{\mathrm{Bk} 3-1}$ & Failure load (KN) & 77.96 & 78.25 & 78.65 & 77.65 & 78.66 & 77.95 & 78.35 & 78.76 & 78.95 \\
\hline Bk3-2 & $\begin{array}{l}\text { Midspan deflection } \\
(\mathrm{mm})\end{array}$ & 7.15 & 6.95 & 7.08 & 7.28 & 7.18 & 7.21 & 7.21 & 7.08 & 6.90 \\
\hline Bk3-3 & Bar diameter (mm) & 16 & 16 & 16 & 16 & 16 & 16 & 16 & 16 & 16 \\
\hline Bk3-4 & Yield Strength, fy (MPa) & 460 & 460 & 460 & 460 & 460 & 460 & 460 & 460 & 460 \\
\hline $\mathrm{Bk} 3-5$ & $\begin{array}{l}\text { Ultimate Tensile } \\
\text { Strength, fu (MPa) }\end{array}$ & 630.7 & 629.5 & 629.9 & 630.7 & 629.9 & 630.7 & 630.7 & 630.1 & 629.7 \\
\hline Bk3-6 & Strain Ratio & 1.32 & 1.31 & 1.30 & 1.30 & 1.30 & 1.31 & 1.30 & 1.32 & 1.32 \\
\hline Bk3-7 & Elongation $(\%)$ & 26.38 & 26.54 & 26.42 & 26.25 & 26.45 & 26.38 & 26.35 & 26.45 & 26.48 \\
\hline
\end{tabular}

TABLE II: Average FleXural Strength of BeAm Specimens (Non-CorRoded, Corrode AND ReSin/ExudATES CoATED SPECIMENS)

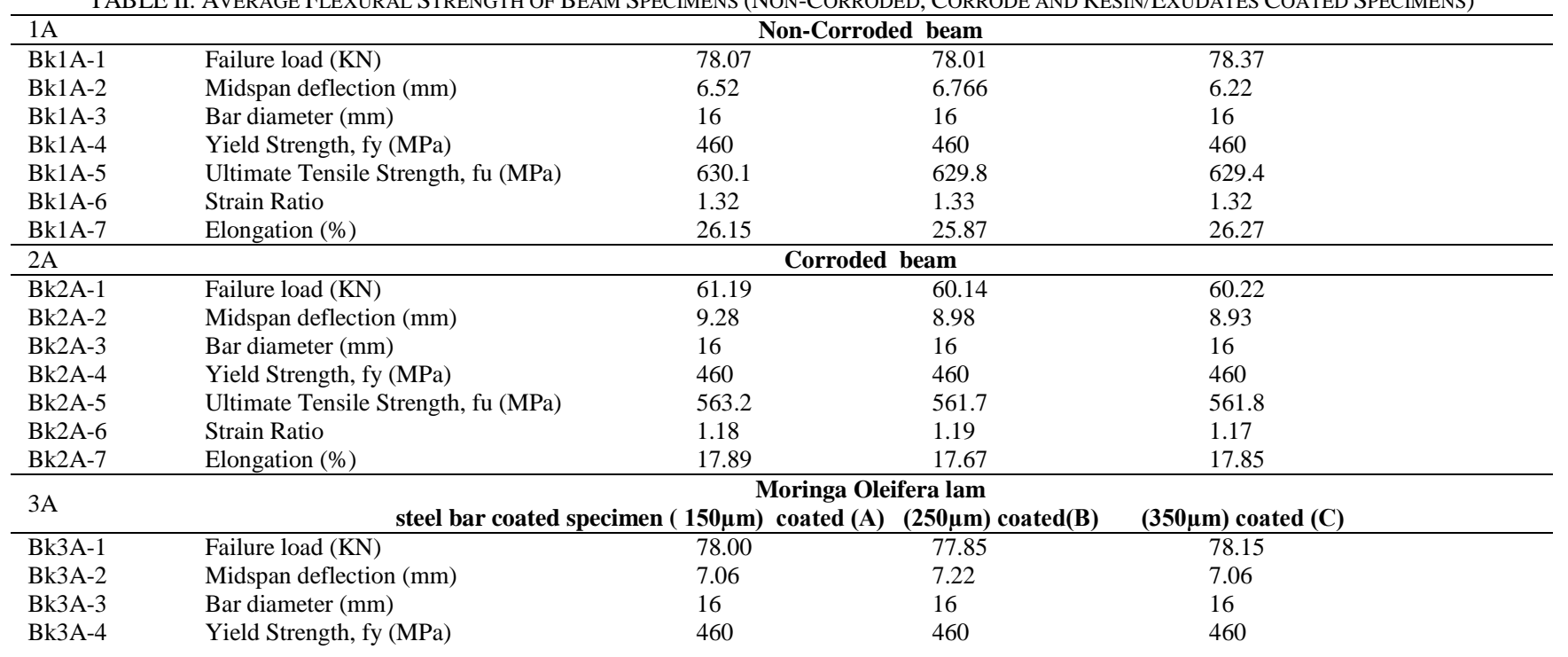


Bk3A-5

Bk3A-6

Bk3A-7
Ultimate Tensile Strength, fu (MPa)

Strain Ratio

Elongation $(\%)$
630.0
1.31

26.44
630.4
1.30
26.36

630.1

1.31

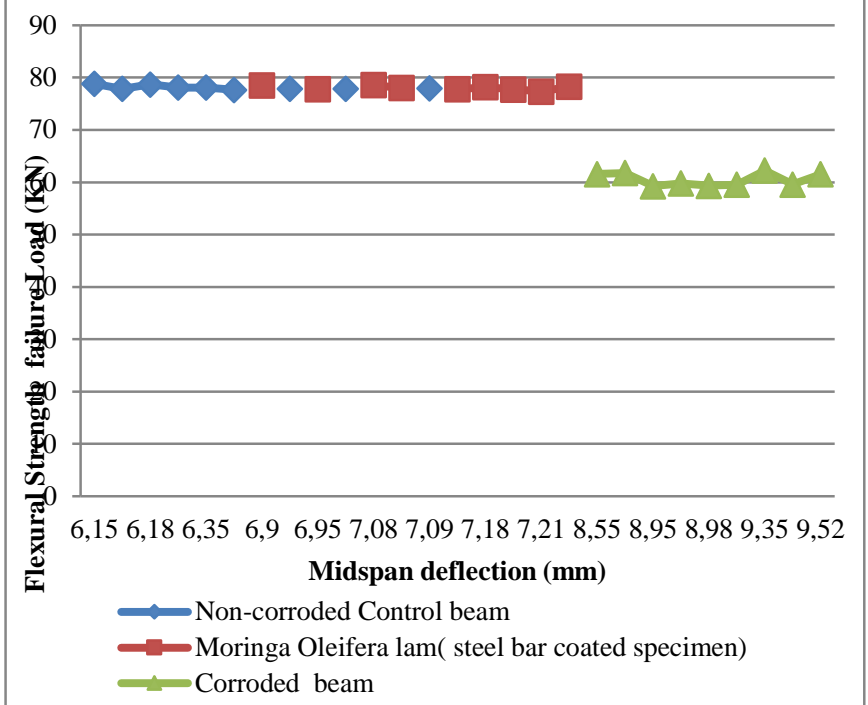

Fig. 1. Failure Load versus Midspan deflection of Beam Specimens (NonCorroded, Corrode and Resin Coated Specimens)

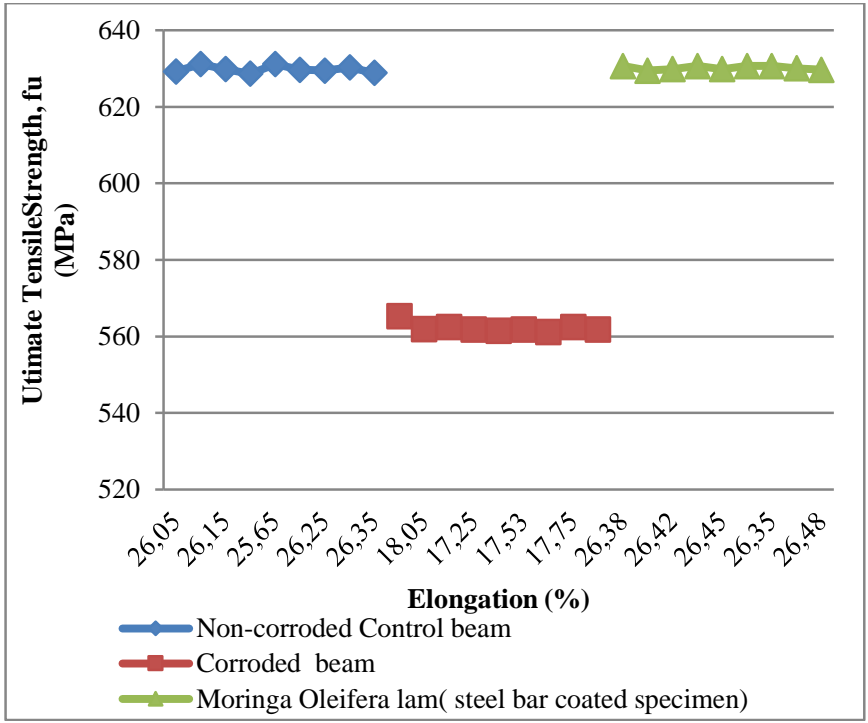

Fig. 2: Ultimate Tensile Strength versus Elongation of Beam Specimens (Non-Corroded, Corrode and Resin Coated Specimens)

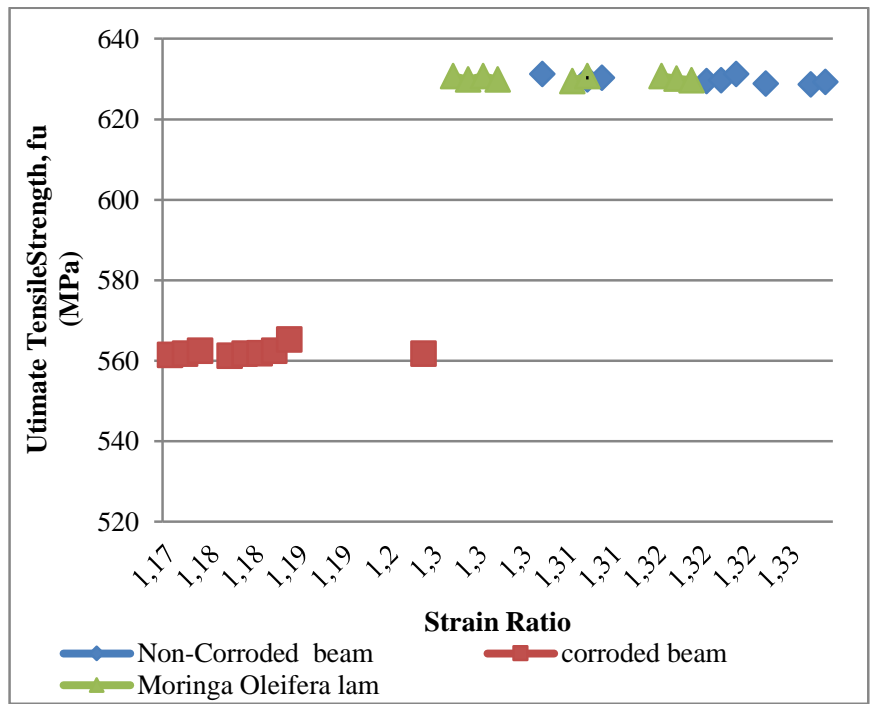

Fig. 3. Ultimate Tensile Strength versus Strain Ratio of Beam Specimens (Non-Corroded, Corrode and Resin Coated Specimens)

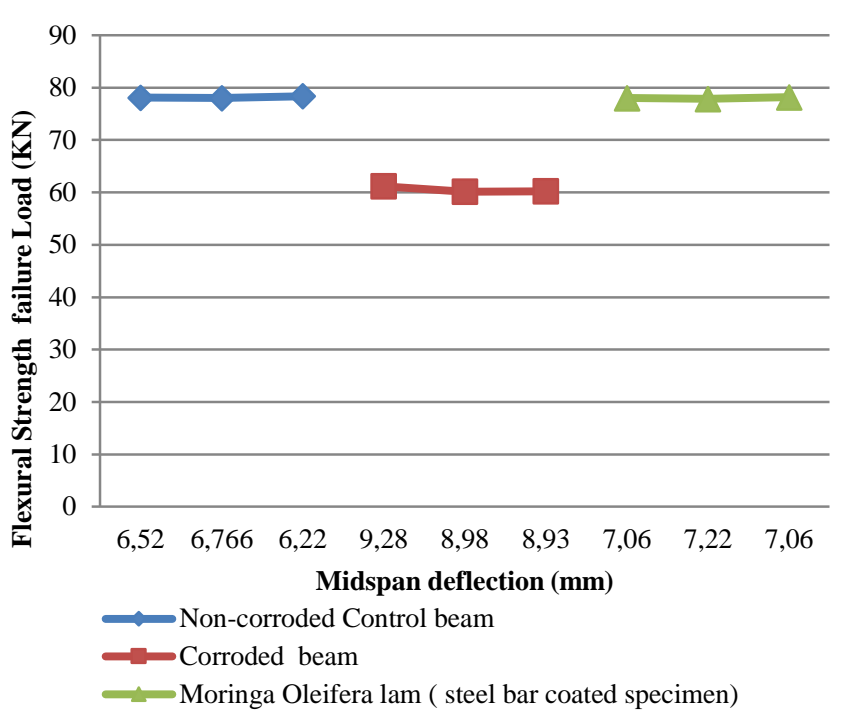

Fig. 4. Average Failure Load versus Midspan deflection of Beam Specimens (Non-Corroded, Corrode and Resin Coated Specimens)

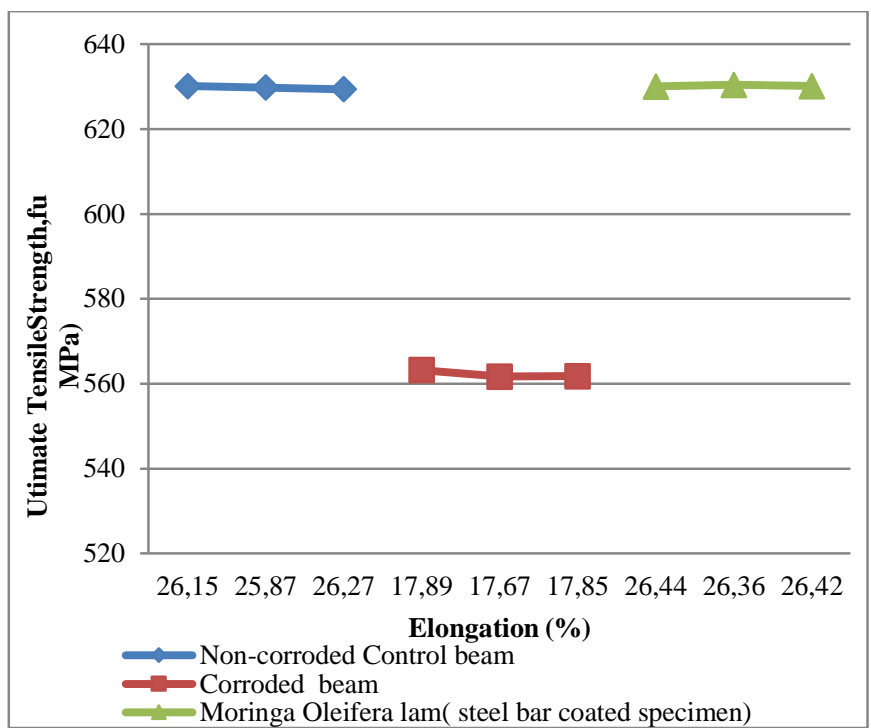

Fig. 5. Average Ultimate Tensile Strength versus Elongation of Beam Specimens (Non-Corroded, Corrode and Resin Coated Specimens)

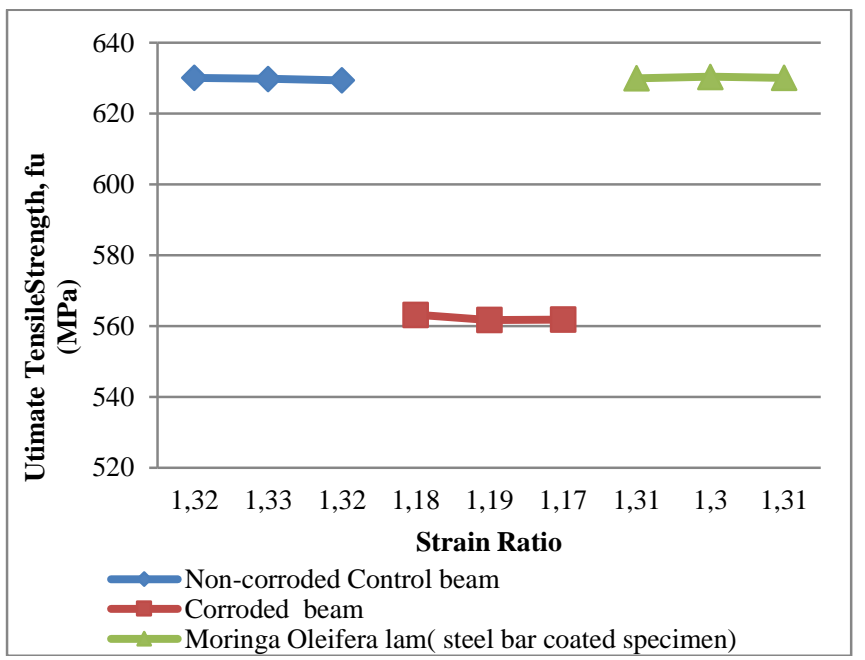

Fig.6. Average Ultimate Tensile Strength versus Strain Ratio of Beam Specimens (Non-Corroded, Corrode and Resin Coated Specimens) 


\section{CONCLUSION}

From Tables I-II and Figs. 1-6, the under listed conclusions were made from the experimental results:

i. Corroded concrete beam members showed higher failure load values with high deflection compared to non-corroded and inhibited beam members resulting from degradation from corrosion actions.

ii. Uncoated concrete beams showed corrosion potential with cracks and spalling.

iii. Resins/ Exudates (inhibitors) did not add strength to investigated members but serves as protective coat.

iv. Surfaces changes was observed in uncoated member due to corrosion attack

\section{REFERENCES}

[1] A. Almusallam, S. Ahmed, , A. Gahtani, and A. Rauf, "Effect of Reinforcement Corrosion on Bond Strength", Construction and Building Materials, vol.10, pp.123-129, 1995.

[2] J.G. Cabrera, P.A. Claisse, and D.N. Hunt, "A Statistical Analysis of the Factors which Contribute to the Corrosion of Steel in Portland Cement And Silica Fume Concrete", Construction And Building Materials,vol. 9, pp.105-113,1995.

[3] M.H., Rashid, S. Khatun, S.M.K. Uddin, and M.A, Nayeem, "Effect of Strength and Covering on Concrete Corrosion", European Journal of Scientific Research, vol. 40, 492-499, 2010
[4] Malumbela, G., Moyo, P. and Alexander, M. (2009). Structural Behavior of Beams Under Simultaneous Load and Steel Corrosion. Proceedings of the 2nd International Conference on Concrete Repair, Rehabilitation and Retrofitting (ICCRRR), Cape Town, South Africa, November 24-26, (pp. 645-650).

[5] A.W. Otunyo, and C. Kennedy, "Effect of Corrosion on Flexural Residual Strength and Midspan Deflection of steel coated with Resins / exudates of Trees Reinforced Concrete Beams under Sodium Chloride Medium", European International Journal of Science and Technology, vol.6, pp.2304-9693.

[6] A. A Torres-Acost., S. Navarro-Gutierrez, and J. Terán-Guillén, "Residual Flexure Capacity of Corroded Reinforced Concrete Beams", Engineering Structures, vol. 29. no.6, pp.1142-1152, 2007

[7] Ell-Maaddawy, T. E., Soudki, K. and Topper, T. (2005). Analytical Model to Predict Nonlinear Flexural Behavior of Corroded Reinforced Concrete Beams. American Concrete Institute Structural Journal, vol.102, no.4, pp. 550-559, 2005

[8] R. Huang, and C. C. Yang, "Condition Assessment of Reinforced Concrete Beams Relative to Reinforcement Corrosion", Cement and Concrete Composites, vol.19, pp 131-137, 1997.

[9] BS 882; - Specification for aggregates from natural sources for concrete, British Standards Institute. London, United Kingdom, 1992.

[10] BS EN 196-6; - Methods of Testing Cement. Determination of fineness, British Standards Institute. London, United Kingdom, 2010.

[11] BS 12390-5; 2005 - Testing Hardened Concrete: Flexural Strength Test of Specimens, British Standards Institute. London, United Kingdom, 2005.

[12] BS 12390-5; 2005 - Testing Hardened Concrete: Flexural Strength Test of Specimens, British Standards Institute. London, United Kingdom, 2005. 